\title{
Original Solutions for Structural and Functional Rehabilitation of Masonry Buildings
}

\author{
Kubilay Kaptan** \\ * International Blue Crescent Relief and Development Foundation, Center for Humanitarian Studies, Bagdat Caddesi Dorsan \\ Apt. No:467/9, Suadiye - Kadıkoy Istanbul Turkiye 34740 \\ kaptankubilay@gmail.com
}

${ }^{\ddagger}$ Kubilay Kaptan, Bagdat Caddesi Dorsan Apt. No:467/9, Suadiye - Kadıkoy Istanbul Turkiye 34740, Tel : +90 21638414 86-87, Fax : +90 21636157 45, kaptankubilay@ gmail.com

Received: 11.05.2015 Accepted:20.06.2015

\begin{abstract}
The paper presents strengthening solutions and elements of functional rehabilitation for a certain class of 2-4 storied historical buildings of masonry structure. In order to protect the ornamental plastering of the ceiling, an original technology of rehabilitation for large spanned timber slab structures was performed. The worked out technical solution was applied on several buildings. It is presented on the case of a historical building from the $19^{\text {th }}$ century. This case also gives the opportunity to emphasizing the functional improvement of the building.
\end{abstract}

Keywords Structural rehabilitation, masonry buildings, historical buildings, strengthening, omamental plastering.

\section{Introduction}

At the time of 17th to 19th centuries, from Baroque to Eclectic era, a large number of 2-4 storied masonry buildings were performed all across Middle-East Europe. Most of them public buildings are functioning even today. So there are the Palace of Justice in Odorheiu-Secuiesc (Figure 1) and the Palace of Justice in Miercurea-Ciuc (Figure 2), both in Transilvania.

Generally, the supporting structure of these buildings consists of: brick or/and stone-walls and pillars as vertical supporting elements, respectively brick and/or stone bridging elements like masonry arches and vaults, barrel vaults with metal beams or timber slabs as horizontal bearing structures [1], [2] and [3]. Many of these buildings present serious damages today, influencing the reliability of them concerning serviceability limit state and even ultimate limit state requirements [4].

In previous studies [5], [6] different types of historical masonry vaults and slab structures were defined and classified. Their characteristic deficiencies and damages were also put into evidence. A convenient and objective approach of the technical state of the building was proposed and solutions of strengthening were presented [7], [8].

At this time, the purpose is to present some special strengthening techniques corroborated with architectural and functional demands in the frame of the general rehabilitation of the building [9]. The necessity of functional improvement of the old buildings has to be also discussed. These purposes are developed through a significant case (Figure 1).

\section{Description of the Building}

\subsection{Historical considerations}

The Palace of Justice in Odorheiu-Secuiesc is a representative example of many administrative buildings constructed in Transilvania during the 19th century [10], [11]. These buildings responded to the main process of reorganizing and developing the whole system of justice. In this order, the Palace of Justice in Odorheiu-Secuiesc was finished and put in function in 1835 [12].

\subsection{Structural and architectural description}

The palace initially housed not only the trials, but also the prison. Consequently, the organization of the interior spaces corresponded to the functional requirements of that time. It is a two-storied building with basement (Figure 1). 


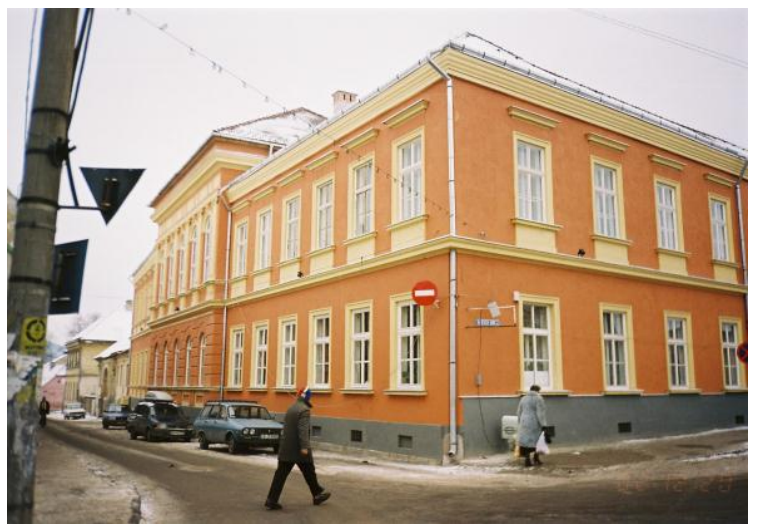

Fig. 1. Palace of Justice in Odorheiu-Secuiesc

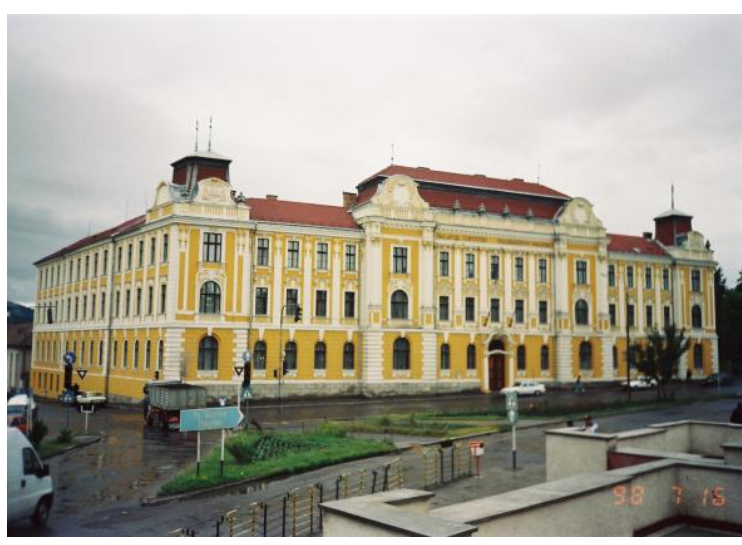

Fig. 2. Palace of Justice in Miercurea-Ciuc

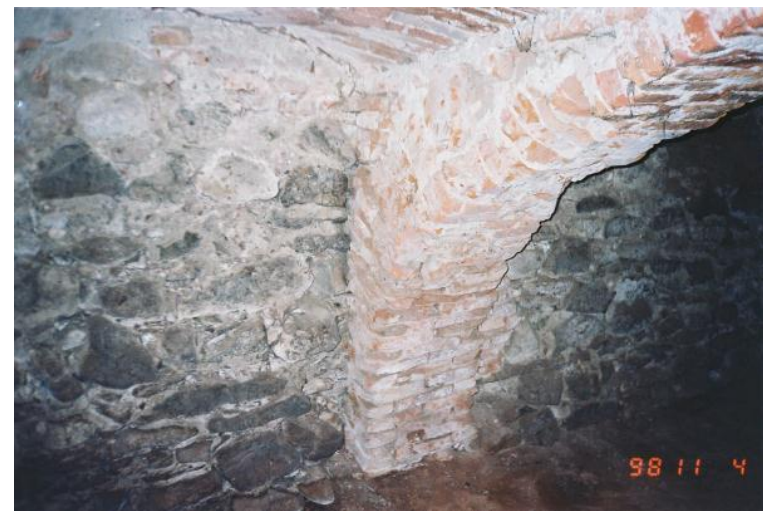

Fig. 3. Masonry stone walls, brick arch and vault

The structure of the cellar is of masonry stone walls sustaining brick arches and vaults (Figure 3).

The structure of the ground floor and first floor consists in brick masonry walls and timber slabs. The roof structure is of main timber trusses of Eclectic type. The whole building can be classified as Eclectic, with late Baroque influence [13], [14], [15].

\section{The General Rehabilitation Process}

The rehabilitation of the Palace of Justice was carried out in the years $1999-2003$. The diagnosis of the building put into evidence the necessity of a capital repair and also consolidation of some subassemblies of the structure in order to reassure the resistance and serviceability of the building [16]. On the other hand, actual demands of functionality imposed its extension, by adding a new block to the old building.

\subsection{Consolidation of the masonry vault system over} the basement

The masonry vault system of the basement is supported by masonry arches and walls (Figure 3). It is to be mentioned the pronounced flatness of the brick arches.

The examination of the masonry vaults and arches put into evidence two main aspects: cracks and breaks with detached bricks on the one hand and important vertical displacements on the other hand. Obviously, the vault system had to be discharged [17], [18]. For this purpose, a new independent slab system was performed over the initial bearing system (Figure 4). It consists in a reinforced concrete slab on metal beams leaning on the stone walls. So, the vaults and arches have to carry only their own weight. The detached and destroyed pieces of brick were replaced with new ones and the masonry joints were filled with lime mortar with powdered brick as hydraulic additive.

\subsection{Consolidation of the timber slab system over the first} floor

The ordinary timber slab over the ground floor and first floor consists in wooden beams bridging the shorter opening between the supporting masonry walls. Their diagnostic, repair and consolidation represented usual engineering tasks. The strengthening solution was: discovering the timber beams, replacing or repairing them, their treatment with antiseptic and fire protection substances, using them as shuttering for the new reinforced concrete slab [19]. The ventilation of the old timber slab was assured by providing a slit between the lower face of the old timber slab and the false ceiling attached to it. Holes of ventilation were provided along the perimeter and around the lamps.

The main technical problem was the rehabilitation of the slab system over the Great Judgement Hall on the first floor. Originally, it is a timber slab system covering a surface of $11.50 \times 10.50 \mathrm{~m} 2$. The slab system consists in a girder network of main and secondary timber beams supported by the perimeter walls. A number of three main beams crosses a span of $10.50 \mathrm{~m}$, placed at a distance of approximately $2.80 \mathrm{~m}$ one from the other, thus creating a number of four $2,80 \mathrm{~m}$ long openings for the secondary beams. Double boarding is fixed on the upper, respectively on the bottom face of the grid. The original ceiling was realized by a decorative plastering on a reed sheet fixed to the inferior boarding. On its upper side the slab structure was completed with thermal slag insulation and brick covering. 


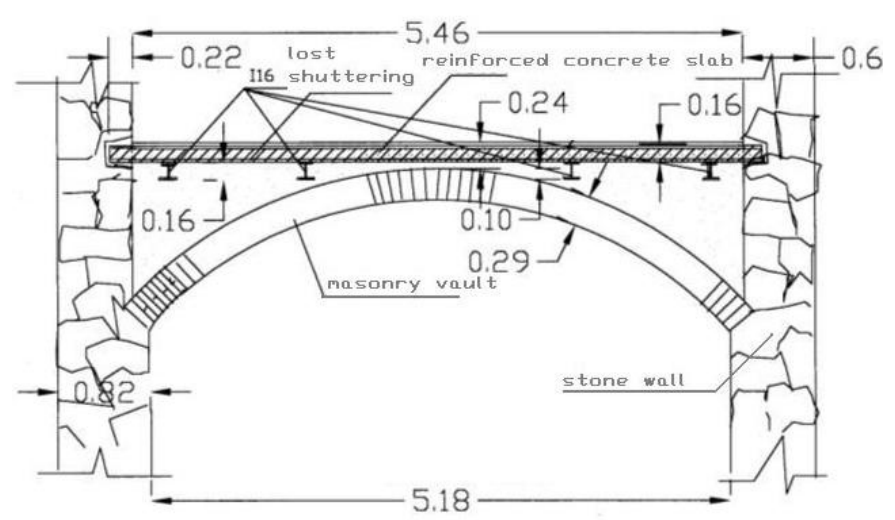

Fig. 4. Consolidation of the slab system over the basement

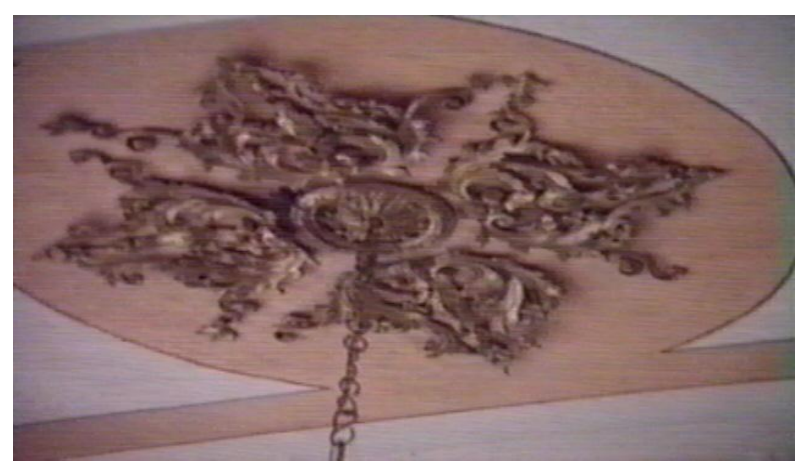

Fig. 5. Plastering in stucco of the ceiling

The most inconvenient phenomenon was the great deflection of the slab, respectively of the main beams. The measured vertical displacements at the middle of the beams were between 11 and $14 \mathrm{~cm}$. This phenomenon caused serious damages, i. e. visible cracks in the ornamental stucco plastering of the ceiling (Figure 5).

The aim was to find a technique of intervention to diminish the deflections saving the ornamental plastering of the ceiling too. For this purpose it was necessary to bring the timber slab back near to its initial form [20], [21]. In this respect, at first, the slab has been discharged taking away the vertical loading given by the floor (thermal insulation and bricks). Secondly, the middle of the main beams had to be lifted for diminishing the vertical deflections. The solution was to build over each main timber beam an independent reinforced concrete girder (Figure 6) supported by the marginal walls.

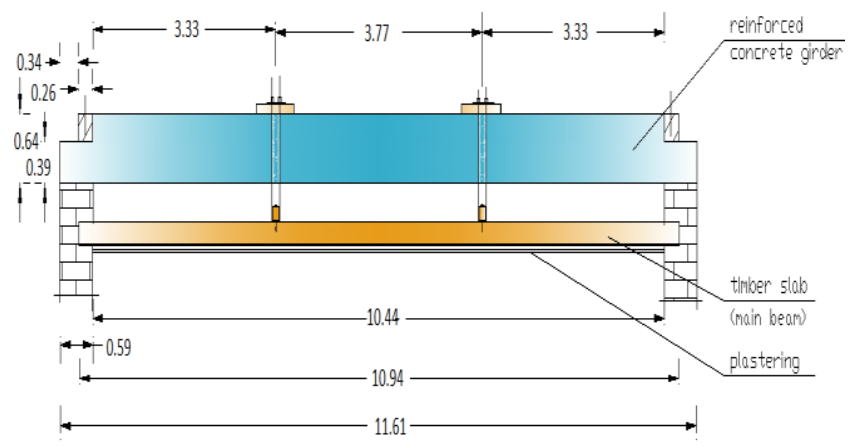

Fig. 6. Lifting girder
An additional temporary sustaining system was conceived to sustain the shuttering, the reinforcement and the cast concrete of the lifting girder. It consists in a triangular timber structure with a tie-rod (Figure 7 and Figure 8) to which the vertical loading is transferred by a series of vertical metal bars.

A transverse section of the whole lifting system, after striking the reinforced concrete girder, is presented in Figure 9.

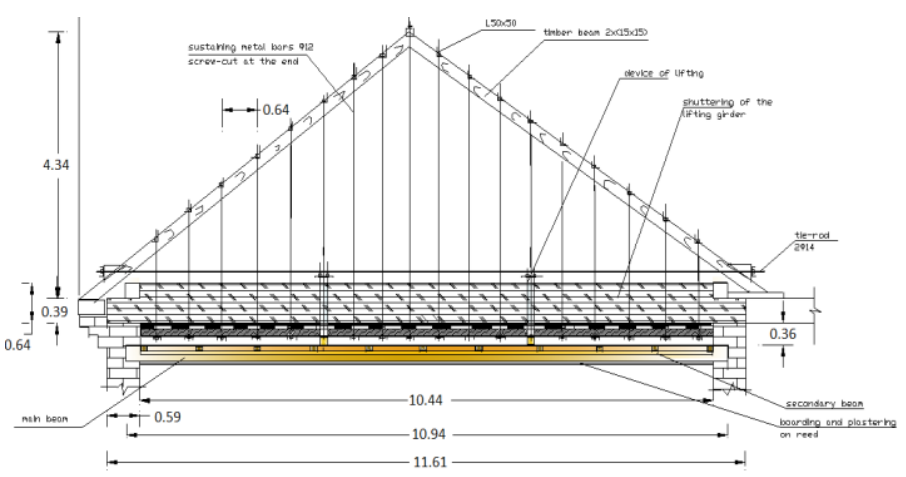

Fig. 7. Additional supporting structure of the lifting girderdesign

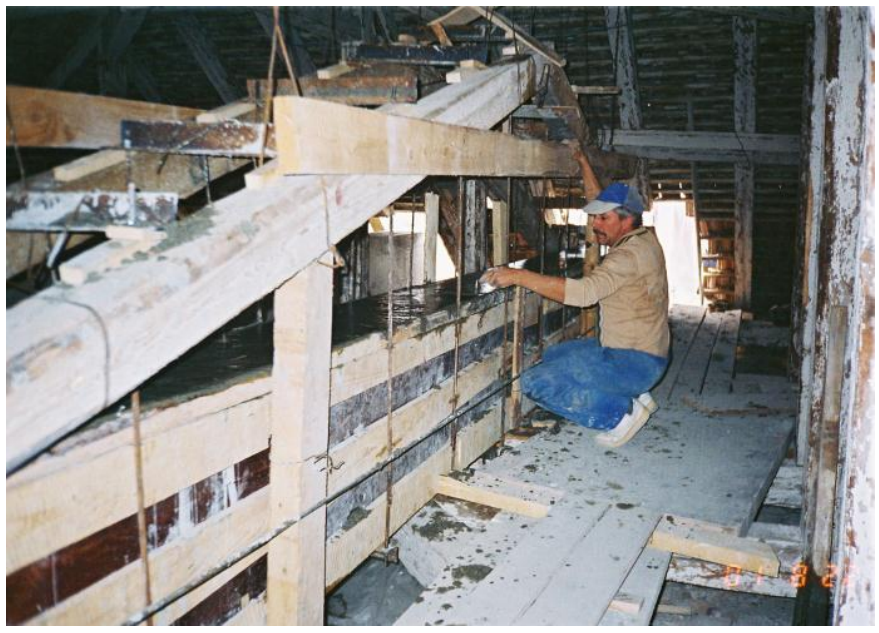

Fig. 8. Additional supporting structure of the lifting girder- photo

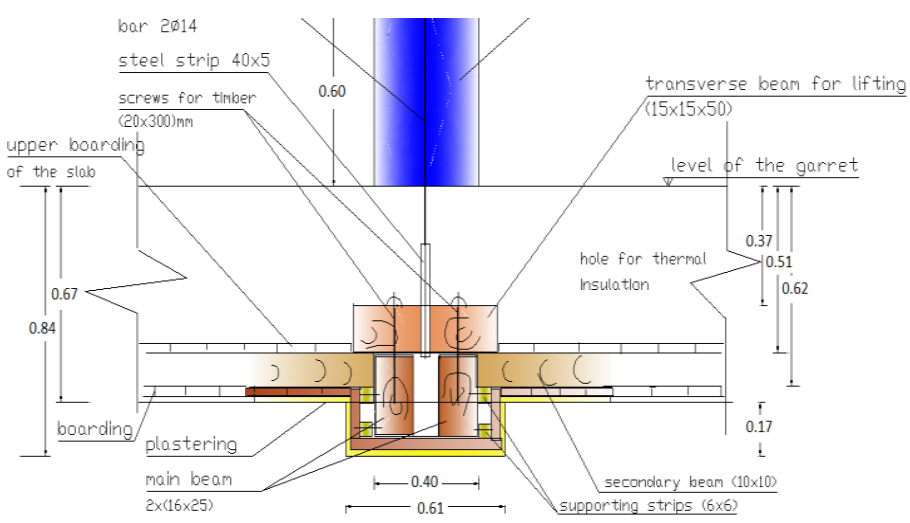

Fig. 9. Transverse section of the lifting system 
The operation of lifting can be performed in two ways:

(a) Lifting the slab before casting the girder, using the additional timber structure for lifting; in this way the bottoming of the two lifting bars is made automatically by the concrete hardening; a relatively short time for the operation can be assured (7-8 days);

(b) Lifting after the execution of the reinforced concrete girder; the lifting bars pass through the girder by former embedded tubes; it has the advantage of a perfectly controlled way of lifting and bottoming the lifting bars on the girder surface by screwed devices; the time of operation is relatively long because of the hardening time of the concrete;

In this way the middle of the main beams could be lifted with $8-9 \mathrm{~cm}$ without displacements of the supports. This rising of the axes of the beams was enough to close the cracks of the ornamental plastering and finally permitted a proper restoration of the ceiling.

\subsection{Functional rehabilitation}

For improving the circulation flux in the building and also responding to the actual requirements concerning emergency evacuation, a new staircase was added to the old building [22], [23]. The originality of the solution consists in the fact that the architect didn't try to take again the initial style of the building [24], [25]. On contrary, aiming to a maximum functional and structural efficiency, a very modern solution in reinforced concrete and glass was adopted (Figure 10, Figure 11).

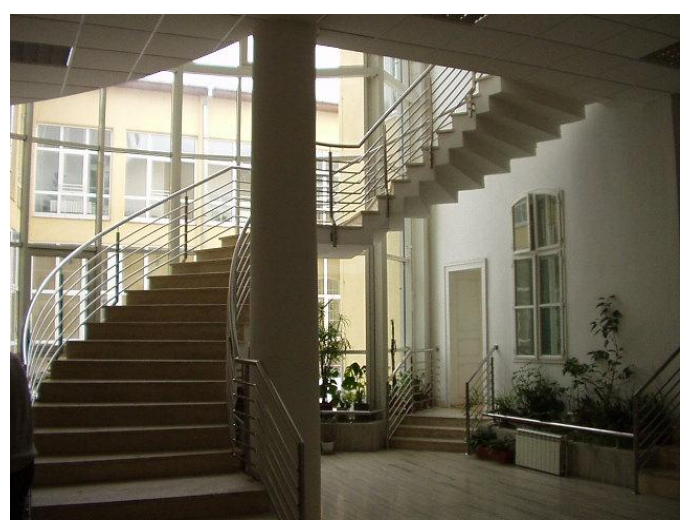

Fig. 10. New staircase - interior view

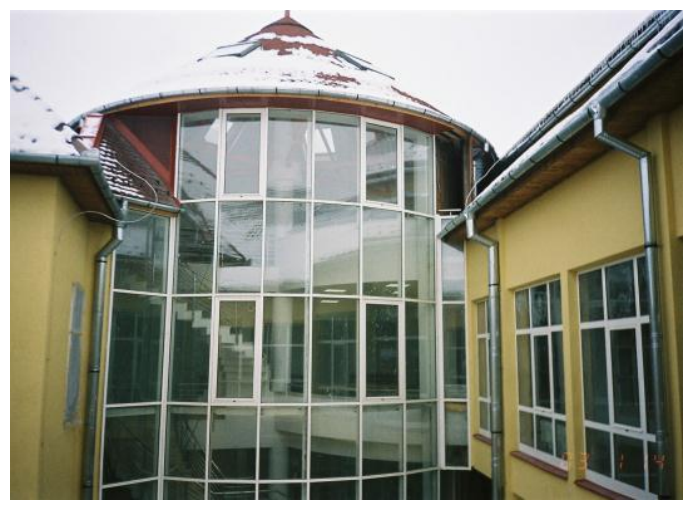

Fig. 11. New staircase - exterior view

\section{Conclusions}

The study put into evidence one of the major dilemma of the rehabilitation process: the necessary balance between preserving the valuable historical characteristics of an old building and today's requirements concerning the safety, serviceability and functionality of the building.

The paper presents an original technical solution for consolidating large spanned timber slab structures saving architectural values as well. The solution consists in diminishing the vertical deflection of the slab by using a special lifting system.

Modern architectural solutions can be successfully used in order to improve the functionality of the historical buildings, without disturbing, on the contrary, emphasizing their historical character.

\section{References}

[1] Ahmad Hamid, 2012, Design and Retrofit of unreinforced Masonry Structures, FUNDEC course on. Lisbon, February 6, 2012.

[2] Appleton J, 2009, Técnicas de reabilitação de estruturas de alvenaria, Seminar "Patologia, Inspecção e Reabilitação de Edificios tradicionais" (in Portuguese).

[3] Appleton, J., Reabilitação de Edifícios Antigos Patologias e tecnologias de intervenção, Edições Orion, $1^{\text {a} E d i c ̧ a ̃ o, S e t e m b r o ~ d e ~} 2003$ [in Portuguese].

[4] Amadio C., Gattesco N., Dudine A., Franceschinis R., Rinaldin G., 2012, Structural performance of spandrels in stone masonry buildings, Proc. of the 15th World conference on Earthquake. Engineering, pp 5077, Lisbon, Portugal.

[5] Bucur-Horváth, I., Popa, I., Tanasoiu, I. 2000, "Study on old masonry structures in brick vaults", 2nd International Congress on Studies on Ancient Structures, Istanbul, pp. 311-322.

[6] Bucur-Horváth, I., Popa, I, Bacsó, Á, Puskás, A. 2001, "Approaches of the technical state and behaviour for old structures in brick vaults", 3rd International Seminar on Historical Constructions. Possibilities of numerical and experimental techniques. Guimarães, Portugal, pp. 283291.

[7] Arifuzzaman S. and Saatcioglu M., 2012, Seismic Retrofit of Load Bearing Masonry Walls by FRP Sheets and Anchors, Proc. of the 15th World conference on Earthquake Engineering, pp 4501, Lisbon, Portugal.

[8] Cóias e Silva V (2007) Reabilitação Estrutural de Edifícios Antigos-Alvenaria, Madeira-Técnicas pouco intrusivas. Ed. Argumentum \& Gecorpa, Lisbon, Portugal (in Portuguese).

[9] Costa A., 2008, Notes from the post9 graduation course on rehabilitation of constructions - Stone Masonry structures. 
[10] Cruz H., FUNDEC course on Rehabilitation techniques of constructions, wood structures, IST 923 Jan to 3 Fev 2012.

[11] Ingham, J., 2012, FUNDEC one day lecture on the "Seismic assessment and improvement of unreinforced masonry buildings", IST.

[12] Kabir M. Z., Kalali A., Shahmoradi R., 2012, Cyclic Behavior of Perforated Masonry Walls

[13] Strengthened with Fiber Reinforced Polymers, Proc. of the 15th World conference on Earthquake Engineering, pp 3734, Lisbon, Portugal.

[14] Lourenço, P. "Reabilitação de edifícios de alvenaria e adobe". Lectures on the rehabilitation of masonry structures, University of Minho.

[15] Ma R., Jiang L., He M., Fang C., Liang F., 2012, Experimental investigations on masonry structures using external prestressing techniques for improving seismic performance, Engineering Structures 42 (2012) 297-307.

[16] Magenes G., Penna A., Rota M., Galasco A., Senaldi I., 2012, Shaking table test of a full scale stone masonry building with stiffened floor and roof diaphragms, Proc. of the 15th World conference on Earthquake Engineering, pp 5320, Lisbon, Portugal.

[17] Mahdizadeh A., Borzouie J., Raessi M., 2012, New Approach to seismic Rehabilitation of Masonry School Buildings, Proc. of the 15th World conference on Earthquake Engineering, pp 2851, Lisbon, Portugal.

[18] Mayorka P. and Meguro K, 2008, "A step towards the formulation of a simple method to design PP9Band mesh retrofitting for Adobe/Masonry houses", 14th World Conference on Earthquake Engineering, Beijing, October 2008.

[19] Meireles, HA, 2012, Seismic vulnerability of Pombalino buildings, PhD Thesis, IST, Portugal (in English).

[20] Parisi M.A., Chesi C.,Tardini C., 2012, The Role of Timber Roof Structures in the Seismic Response of Traditional Buildings, Proc. of the 15th World conference on Earthquake Engineering, pp 2394, Lisbon, Portugal.

[21] Robinson L, Bowman I, 2000, Guidelines for Earthquake Strengthening, New Zealand, Historic Places Trust, Wellington, NZ.

[22] Roque, J. A., 2002, "Reabilitação Estrutural de Paredes Antigas de Alvenaria". Master Thesis University of Minho, Setembro 2002. (www.civil.uminho.pt/masonry) (in Portuguese).

[23] Santos S.P. (reporter), 2010, Guide for the Structural Rehabilitation of Heritage Buildings, CIB Publication 335, June 2010.

[24] Santos, S.P., 2003, "Structural Rehabilitation of Historic Buildings", 40th Meeting of Commission CIB W023, Padova, Italy, (in CD9ROM).
[25] Shrestha H., Pradhan S., Guragain R., 2012, Experiences on Retrofitting of Low Strength Masonry Buildings by Different Retrofitting Techniques in Nepal, Proc. of the 15th World conference on Earthquake Engineering, pp 2012, Lisbon, Portugal. 